\title{
28 Resarch Square \\ Elevator (Lift) Car Ventilation Design to Mitigate the Risk of Spread of COVID-19
}

\author{
Pravin M. Tipnis \\ Vinay G. Vaidya ( $\sim$ pifocal@gmail.com ) \\ Pi Innovate
}

\section{Research Article}

Keywords: Coronavirus, COVID-19, Elevator design, Elevator ventilation Fan, Air changes

Posted Date: June 14th, 2021

DOI: https://doi.org/10.21203/rs.3.rs-618512/v1

License: (1) This work is licensed under a Creative Commons Attribution 4.0 International License.

Read Full License 


\title{
Elevator (Lift) Car Ventilation Design to Mitigate the Risk of Spread of COVID-19
}

\author{
Pravin M. Tipnis - Vinay G. Vaidya*
}

Received: date / Accepted: date

\begin{abstract}
Recent studies, on the airborne transmission of the SARS-CoV-2 and the new CDC guidelines confirming the aerosol transmission of the virus, make immediate attention to the airflow in elevators imperative. While several versions have been thought of for contactless rides, there is little that has been considered for lessening the anticipated viral load in the elevator car.

In this paper, a two-step approach is used. The first is the risk assessment, and the second is the risk mitigation through an improved lift car ventilation design. The risk is assessed by computing the probable viral load during the journey in a lift car. It is seen that the ventilation typically provided as per the minimum permissible requirements by codes is inadequate to handle the current situation.

The computations show that one-minute exposure, to a coughing high emitter in the lift car, creates a viral load to dangerous levels well above the possible acceptable level of 10,000 virus copies $/ \mathrm{m}^{3}$. To come up with the risk mitigation strategies, the required ventilation in the car was computed. The main recommendation suggests the use of forced ventilation using pressure fans and 3 to 6 air changes per minute depending on the operating environment. Such a design will help us achieve our objective of bringing the density of virus copies in the lift car to an acceptable level. A properly designed ventilation system for the elevator car will benefit in both pandemic situations as well as nonpandemic situations.
\end{abstract}

Keywords Coronavirus · COVID-19 - Elevator design · Elevator ventilation Fan - Air changes

Pravin Tipnis

Pi Innovate, India

E-mail: pravinmtipnis@gmail.com

Vinay Vaidya

Pi Innovate, India

E-mail: vaidya.vinay@gmail.com 


\section{Introduction}

The present coronavirus pandemic has spread rapidly all over the world. COVID-19 transmission happens through physical contact and aerosol transmission (Martin Z. Bazant and John W. M. Bush 2021). Individuals with asymptomatic or mild coronavirus disease 2019 (COVID-19) have been reported to frequently transmit the disease even without direct contact. Naturally, people are concerned about coronavirus transmission in enclosed spaces. Thus, there is always some anxiety about the coronavirus transmission during the lift (elevator) rides. In the context of lift travel, the spread is likely from both the channels; direct contact as well as aerosol transmission.

To avoid touching call registration buttons with one's fingers, many applications have been developed which register lift calls by mobile phones using QR code, dedicated app, or using infrared sensors to call the lift and point their finger towards a floor number as a command for the designated floor, or by foot-operated switches, etc.

Much literature could not be found on the possibility of the spread of the virus through the air during the travel in the lift car. On the face of it, the time spent in the lift car by a person is minuscule, thus one may conclude that the risk factor is not huge.

However, the elevator car is a small room and people easily spend a few minutes in it. In the absence of a good ventilation system for the lift car, the viral load in the car can assume dangerous levels which keep lingering in the air in the car. Thus, persons traveling in such an atmosphere would be at a risk. Significantly, passengers need not travel together with such virus-infected person(s) to get affected by the virus because the virus can survive up to 3 hours in aerosols (Shen J. et al 2020). It is evident by the research carried out by Marr's team that the SARS-CoV-2 is airborne. Thus, it is important to study the airflow in elevators and how to alleviate the airborne transmission of the SARS-CoV-2 (Tang, J. et al (2021); Miller, Shelly L. et al (2021); Tang, Julian W., et al (2021)).

An attempt has been made in this paper to link the probable time spent by the passengers in the lift car during travel and the viral load that they may get exposed to during that time; thus arrive at the risk factor. The typical ventilation system of the lift car is analyzed and used to estimate the viral load that may exist in the lift car. The viral loads are estimated in the research paper (Riediker and Tsai 2020) as cited which are used in this analysis.

\section{Literature Survey}

Existing lifts follow the lift codes/standards applicable in the country where the lift is installed. Here four standards are reviewed, namely, the ISO standards, the Indian standards, the American standards, and the European standards for the lift car ventilation requirements. 
2.1 The International Standards Organisation's standard on lifts ISO 8100-1: Lifts for the transport of persons and goods (ISO Standards 2019) stipulates:

\subsubsection{Ventilation}

5.4.9.1 Cars shall be provided with ventilation apertures in the upper and lower parts of the car.

5.4.9.2 The effective area of ventilation apertures situated in the upper part of the car shall be at least $1 \%$ of the available car area, and the same also applies to the apertures in the lower part of the car.

The gaps (a) around the car doors may be taken into account in the calculation of the area of ventilation holes, up to $50 \%$ of the required effective area.

5.4.9.3 Ventilation apertures shall be built or arranged in such a way that it is not possible to pass a straight rigid rod $10 \mathrm{~mm}$ in diameter through the car walls from the inside.

2.2 The Indian Standard on Lifts IS 14665 Part 4 Section 3 (Bureau of Indian Standards 2001) stipulates:

5.4 Where the lift car has a solid enclosure and doors, provisions shall be made for a fan and adequate ventilation. To permit switching off the power supply to the lift without switching off the fan and light, a separate circuit with control in the machine room shall be provided for fan and light. Ventilation openings shall be provided in the enclosure above $1.8 \mathrm{~m}$ level and below $0.3 \mathrm{~m}$ levels. The total area of openings shall be not less than $0.035 \mathrm{~m}^{2}$ for each square meter of an area of the car floor divided suitably between the top and the bottom levels. Any openings provided by a ventilating fan may be regarded as forming part of the ventilation area in that part of the car in which it is fitted.

In India, the typical lift car ventilation system consists of one or more fans, usually either axial flow or cross-flow type. Ventilation holes are provided above the ceiling and near the floor. The holes are often hidden due to safety and aesthetic reasons.

2.3 The American standard for elevators ASME A17.1 (American Society of Mechanical Engineers 2001) and the Indian Standard IS 14665 more or less match in terms of requirements for area of ventilation apertures, locations of apertures, etc.

2.4 The European standard for lifts En 81-20 (European Committee for Standardization EN 81) and ISO 8100-1 are identical as the latter is based on the former.

Compliance with the Lift Standards may not tackle the issue of the spread of the COVID-19 virus during a ride in the lift car. 
It may be noted that the present Indian Standard IS 14665 Part 4 Section 3 and the American standard ASME A17.1 call for a minimum of only $3.5 \%$ of floor area for ventilation purposes to be divided equally at the top and the bottom portion of the car.

The ISO and EN standards require even lesser minimum ventilation areas, just $2 \%$ of floor area and there is no mention of the requirement of a fan. Essentially, these are only natural ventilation openings; and there is no specified value for air changes.

Some air in the car near the doors may get exchanged with outside air when the lift doors are open, however, the air towards the backside of the lift car, especially in a deep car, may remain stagnant.

Thus, it is not difficult to guess that the minimum ventilation provided as per codes will not serve the purpose of effective air changes considering the following points:

- The minimum areas for ventilation of the lift car specified in various codes appear to be very small.

- Due to aesthetic and safety considerations, the ventilation openings are hidden adding to the resistance to airflow.

- Even in the Indian context where the provision of a fan is mandatory, usually, the fan provided is either axial flow type or cross-flow type which cannot push the air in case there is even moderate resistance to the flow of air. This is experienced many times during lift travel. The passengers feel the breeze (movement of air) when the lift car door \& landing door are open, but as soon as they close the breeze disappears. In many cases, the breeze is not felt in either case.

- In practice, if the lift interior is done by a third party, in several cases the ventilation holes are blocked unwittingly by the interior paneling done by the party.

It may, however, be noted that The ASME A17.1, in case of observation elevators with glass walls exposed to direct sunlight, specifies the forced ventilation requirements as stated below:

- There shall be a minimum air handling capacity to provide one air change per minute based on the net inside car volume.

\section{Estimation of Viral Aerosol Emissions from Simulated Individuals:}

Riediker and Tsai (2020) estimated viral aerosol emissions from simulated individuals with asymptomatic to moderate COVID-19 infections. Their work forms the basis of this paper.

Since there is no direct study done on the estimation of viral load emissions in a lift car from individuals infected with coronavirus disease-19, an attempt has been made to derive the same from the studies made by Riediker and Tsai (2020). 
In their study, Riediker and Tsai (2020) estimated the concentration of viral load in a closed room. The air exchange rates were varied. It was presumed that the virus emitter had a high virus load in the lungs and was coughing every 30 seconds intermittently. The study results summarized by them are given in Table 1.

The findings suggest that one may be at the risk of infection if just more than a few minutes are spent in a small room with a COVID-19 infected person with a high viral load.

In conclusion, the authors say "The results of our mathematical modeling suggest that the viral load in the air can reach critical concentrations in small and poorly ventilated rooms, especially when the individual is a super-spreader, defined as a person emitting a large number of micro-droplets containing a high viral load."

For the study, the authors of the above-referred paper have considered a typical medical examination room of volume $50 \mathrm{~m}^{3}$ and considered various air exchange rates from $1 / \mathrm{hr}$. to $20 / \mathrm{hr}$.

Table 1 Air exchange rate and viral concentration (Riediker and Tsai 2020). Plateau Concentration of Different Combinations of Air Exchange Rate, Emission Form, and Emitter Type

\begin{tabular}{|c|c|c|c|c|}
\hline Measure & Air exchange rate, times $/ \mathrm{h}$ & & & \\
\hline & 1 & 3 & 10 & 20 \\
\hline Time until $99 \%$ of plateau, $\mathrm{min}$ & 169 & 77 & 26 & 14 \\
\hline \multicolumn{5}{|c|}{ Airborne viral concentration at plateau, copies $/ \mathrm{m}^{3}$} \\
\hline $\begin{array}{c}\text { Regular Breathing } \\
\text { Lw emitter }\end{array}$ & & & & \\
\hline $\begin{array}{l}\text { Low emitter } \\
\text { Typical emitter }\end{array}$ & $\begin{array}{l}0.000009598 \\
0.009598\end{array}$ & $\begin{array}{c}0.000004310 \\
0.004310\end{array}$ & $\begin{array}{c}0.000001472 \\
0.001472\end{array}$ & $\begin{array}{c}0.000000758 \\
0.000758\end{array}$ \\
\hline High emitter & 1247.7 & 560.3 & 191.3 & 98.6 \\
\hline \multicolumn{5}{|l|}{ Frequent Coughinga $^{\mathrm{a}}$} \\
\hline Low emitter & 0.057251 & 0.025709 & 0.008779 & 0.004524 \\
\hline Typical emitter & 57.251 & 25.709 & 8.779 & 4.524 \\
\hline High emitter & 7442598 & 3342148 & 1141326 & 588093 \\
\hline
\end{tabular}

a Defined as coughing every 30 seconds.

Table 1 gives an estimated concentration of the virus in a closed room of volume $50 \mathrm{~m}^{3}$ for different air change rates with different degrees of emitters over periods. It also shows that the more the air changes per hour lesser is the value of the maximum concentration of the virus and that saturation level is reached in lesser time.

In Table 2, the virus emission rate in no. of copies emitted per minute is derived from the data available in Table 1 for two different air change rates.

The total number of copies in the room $=$ number of copies $/ \mathrm{m}^{3} *$ volume of room $\mathrm{m}^{3}$.

Virus emission rate $=$ a Total number of copies in the room /time durationto accumulate the copies.

Thus, the calculated virus emission rates for the two air change values considered are 2,200,000 and 2,100,000 copies per minute. As expected, the number of copies emitted per minute remains approximately the same and is independent of how many times the air is changed per hour. 
Table 2 The calculated virus emission rate of a high-emitter person coughing, measured in virus copies emitted per minute.

\begin{tabular}{|c|c|c|c|c|}
\hline \multicolumn{5}{|c|}{$\begin{array}{l}\text { The volume of the room }=50 \mathrm{~m}^{3} \\
\text { High emitter with coughing }\end{array}$} \\
\hline Air change rate* & $\begin{array}{l}\text { Time duration for } \\
\text { reaching plateau.* }\end{array}$ & $\begin{array}{l}\text { Total viral load at the } \\
\text { plateau in the room.* } \\
\text { (density) }\end{array}$ & $\begin{array}{l}\text { Total viral load in the } \\
\text { room at the plateau. }\end{array}$ & Virus emission rate** \\
\hline & & & $\begin{array}{l}\text { No of copies = density } \\
\text { copies } / \mathrm{m}^{3} * \text { volume of } \\
\text { room } \mathrm{m}^{3}\left(50 \mathrm{~m}^{3}\right)\end{array}$ & $\begin{array}{l}\text { Total no of copies/time } \\
\text { duration }\end{array}$ \\
\hline No./hr & minutes & copies $/ \mathrm{m} 3$ & $\begin{array}{l}\text { no. of copies (rounded } \\
\text { off) }\end{array}$ & no. of copies/minute \\
\hline 1 & 169 & $7,442,598$ & $372,000,000$ & $2,200,000$ \\
\hline 20 & 14 & 588,093 & $29,400,000$ & $2,100,000$ \\
\hline
\end{tabular}

* Data taken from the table reproduced from the paper by Riediker and Tsai (2020).

** Actual virus emission rate would be higher because the air changes happening in the time duration for reaching the plateau will remove some virus copies.

\section{Calculations of the density of viral load in a lift car of 8 P capacity}

The viral load density, i.e. the number of copies per cubic meter is given by:

The number of copies $/ \mathrm{m}^{3}=$ Number of copies emitted per minute $*$ time oftravel in minutes / Volume in $\mathrm{m}^{3}$.

The volume of a typical lift car of 8 person capacity is $3 \mathrm{~m}^{3}$.

Number of copies $/ \mathrm{m}^{3}=2,200,000$ copies $/ \mathrm{min} * 1$ minute $/ 3 \mathrm{~m}^{3}$

\section{3,000 copies $/ \mathrm{m}^{3}$}

Thus, if the affected person travels in a lift car of $8 \mathrm{P}$ capacity for 1 minute he will emit 2,200,000 copies in the available volume of approximately $3 \mathrm{~m}^{3}$ creating a density of 733,000 copies $/ \mathrm{m}^{3}$.

\section{Calculations of the density of viral load in a lift car of 20 P capacity}

The viral load density, i.e. the number of copies per cubic meter is given by:

The number of copies $/ \mathrm{m}^{3}=$ Number of copies emitted per minute ${ }^{*}$ time oftravel in minutes / Volume in $\mathrm{m}^{3}$.

The volume of a typical lift car of 20 person capacity is $6.3 \mathrm{~m}^{3}$.

Number of copies $/ \mathrm{m}^{3}=2,200,000$ copies $/ \mathrm{min} * 1$ minute $/ 6.3 \mathrm{~m}^{3}$

\section{'349,000 copies/m}

Thus, if the affected person travels in a lift car of $20 \mathrm{P}$ capacity for 1 minute he will emit 2,200,000 copies in the available volume of approximately $6.3 \mathrm{~m}^{3}$ creating a density of 349,000 copies $/ \mathrm{m}^{3}$. 


\section{Calculations of Safe Maximum Density of COVID-19 virus in the} air in a room:

As per the same paper, "a review of a wide range of respiratory viruses suggests that the infective dose is often low. Sometimes as few as a few hundred units of active virus seem sufficient to cause disease."

Tidal volume (TV) measures the amount of air that is inspired and expired during a normal breath of a person. On average, this volume is around one-half liter (Introduction to General Biology). The normal number of respirations for a non-respiratory-compromised healthy adult is between 12 and 20 breaths per minute (Flenady T, Dwyer T, Applegarth J 2017).

Thus, the average breathing volume of a person is $0.01 \mathrm{~m}^{3} / \mathrm{min}$. Depending on several factors including the activities that he has performed, this value could be higher.

As the safe level of viral dose is 100 copies, the acceptable density becomes 100 copies $/ 0.01 \mathrm{~m}^{3}$ per minute of breathing volume $=\mathbf{1 0 , 0 0 0}$ copies $/ \mathrm{m}^{\mathbf{3}}$ for one minute exposure time.

\section{Required air changes for a typical 8 passenger car:}

We have seen in section 4 above that if the affected person travels in the lift car of 8 P capacity for 1 minute he will create a viral density of 733,000 copies $/ \mathrm{m}^{3}$ in the lift car.

Thus, a person exposed to this contaminated atmosphere will inhale 7330 copies per minute of travel time $\left(733,000\right.$ copies $\left./ \mathrm{m}^{3} * 0.01 \mathrm{~m}^{3} / \mathrm{min}\right)$ which is much higher than the required dose of a few hundred copies of the virus to get infected.

Assuming every air change brings down the viral copies by $50 \%$, the number of air changes required to bring down the density of viral copies from 733,000 copies $/ \mathrm{m}^{3}$ to 10,000 copies $/ \mathrm{m} 3$ will be approximately $\mathbf{6 . 2}$ (solving for " $\mathrm{x}$ " from equation $\left.2^{\mathrm{x}}=733,000 / 10,000\right)$.

These many air changes have to be achieved in one minute hence the required volume of air for the eight-passenger lift car would be:

\section{2 changes $/$ minute $\times 3 \mathrm{~m}^{3}$ per change $=\mathbf{1 8 . 6} \mathrm{m}^{3} /$ minute .}

Now, if we assume every air change brings down the viral copies by $75 \%$ (i.e. $25 \%$ continues to remain in the air) then the number of air changes required will be approximately 3.1 (solving for " $x$ " from equation $4^{\mathrm{x}}=$ 733,000/10,000).

These many air changes have to be achieved in one minute hence the required volume of air for the eight-passenger lift car would be:

3.1 changes $/$ minute $\times 3 \mathrm{~m}^{3}$ per change $=9.3 \mathrm{~m}^{3} /$ minute . 


\section{Required air changes for a typical 20 passenger car:}

We have seen in section 5 above that if the affected person travels in the lift car of $20 \mathrm{P}$ capacity for 1 minute he will create a viral density of 349,000 copies $/ \mathrm{m}^{3}$ in the lift car.

Thus, a person exposed to this contaminated atmosphere will inhale 3490 copies per minute of travel time $\left(349,000\right.$ copies $\left./ \mathrm{m}^{3} * 0.01 \mathrm{~m}^{3} / \mathrm{min}\right)$ which is much higher than the required dose of a few hundred copies of the virus to get infected.

Assuming every air change brings down the viral copies by 50\%; the required number of air changes will be approximately 5.13 ( solving for " $x$ "from equation $2^{x}=349,000 / 10,000$ copies $/ \mathrm{m}^{3}$ ).

These many changes have to be achieved in one minute, hence the required volume of air for the twenty passenger lift would be:

5.13 changes $/$ minute $\times 6.3 \mathrm{~m}^{3}$ per change $=\mathbf{3 2 . 3} \mathbf{~ m}^{\mathbf{3}} /$ minute

Now, if we assume every air change brings down the viral copies by $75 \%$; the required number of air changes will be approximately 2.56 ( solving for " $x$ " from equation $4^{x}=349,000 / 10000$ copies $/ \mathrm{m}^{3}$ ).

These many changes have to be achieved in one minute, hence the required volume of air for the twenty passenger lift would be:

2.56 changes $/$ minute $\times 6.3 \mathrm{~m}^{3}$ per change $=\mathbf{1 6 . 1} \mathbf{m}^{3} /$ minute

\section{Discussion}

The above analyses give us the methodology to estimate the required air changesper minute and the volume of air to be extracted per minute for a typicaltravel time of one minute in the lift car. However, if the lift makes severalstops on the way, the passengers may spend much more time in the lift carexposing themselves to a much higher viral load. This is true especially forservice lifts, e.g. lifts at airports where people travel with luggage trollies andspend much more time in the lifts due to higher loading and unloading times.

On the other hand, the use of masks will be helpful in retarding the spread of the virus, however eventually how many people will wear masks all the time is a question mark. Also, how much social distancing will be respected in the lift car will have to be seen.

Also, if the passenger is a high emitter with regular breathing, the chances of spread of the virus are very less as the likely density of the virus will be 1248 copies $/ \mathrm{m}^{3}$ in a time span of 169 minutes in a $50 \mathrm{~m}^{3}$ room as compared to 7.4 million copies/m3 in case of the high emitter with coughing under the same parameters (refer Table no 1 above).

In a worst-case scenario, if a high emitter with coughing travels in a lift car at a peak time, it can create a major hazard with the potential of infecting several persons depending on the traffic load in the lift car at that time because, as discussed earlier, the typical ventilation system of the lift car does not carryout effective air changes; the polluted air will stay in the lift car and affect many 
more persons who might travel in the lift car filled with the polluted air. Especially a deep car is likely to hold polluted air for a longer period at the backside of the car. Even if the affected person is a somewhat moderate emitter, still there is a strong possibility of infection spreading to other passengers during their lift travel.

\section{Lift car ventilation system: Design Recommendations}

\subsection{Use forced ventilation:}

It is suggested that the Natural ventilation concept hitherto used for lift car ventilation be changed. Forced ventilation shall be used based on the required number of air changes. Ideally, the lift car air shall be changed such that the viral load comes to an acceptable level of 10,000 copies $/ \mathrm{m}^{3}$ within one minute when the lift car is ready to take up the next batch of passengers after discharging an affected person who might have traveled in the lift car.

\subsection{Air changes should be 3 to 6 per minute:}

Considering all the factors discussed above, the ventilation of the lift car could be based on 3 to 6 air changes per minute. This number could be lesser for lifts that have light-duty loading and could be higher for a very heavy-duty lift or a hospital lift. The above analyses are done on the assumption that every air change brings down the viral copies by $50 \%$ to $75 \%$. This scavenging efficiency will depend on the airflow pattern created in the lift car. If there is considerable "backflow" or "eddy current", the scavenging efficiency will be less as the contaminated air will not straightway head towards exhaust vents (Brigham R, Machireddy M, Sequeira, Y 2019).

10.3 The lift shaft to be ventilated properly for a constant supply of fresh air:

Air in the lift car will be discharged in the lift shaft which should be ventilated appropriately to the outside air considering that the air in the lift shaft will be used to supply "fresh" air to the lift car.

10.4 Use pressure fans and conduct an air discharge verification study:

It may have to be verified in actual practice what percentage of air is retrained per air change under different operating conditions of the lift such as lift doors opening and closing, nonstop return of the lift from the highest reversal floor, etc. Also, the measurements of resistance to airflow for different models/designs of the lift car need to be carried out for a proper selection of pressure fans and deciding sizes of ventilation apertures, air passages, etc. 
10.5 Design ventilation system sensitive to the direction of lift motion:

The pressure developed by the movement of the lift car in the shaft will also have to be considered while estimating the required static pressure of the fan. This phenomenon in the case of high-speed lifts is generally referred to as the "piston effect" (Bureau of Indian Standards 2016). Perhaps, designing the ventilation system lift-direction-of-motion sensitive such that when the lift moves in the UP direction the ventilation fan(s) which is fixed to the ceiling /roof of the car should push the air in the car down and vice versa using separate fans for UP and DOWN directions of motion if necessary, will be more effective and require less static pressure from the fans. Of course, in any case, care has to be taken not to allow any short-circuiting of the airflows, otherwise, the purpose of supplying clean air in the cabin will not be achieved as intended.

This system will have to be evaluated in the overall context of ride comfort from the point of view of noise and vibrations in the lift car.

10.6 Check for the air pressure build-up in the car

Insofar as the discomfort experienced by passengers in mid-rise and high rise lifts on their ears is concerned, the same is primarily attributed to the atmospheric pressure change due to the height difference; however, in addition, the same could also be attributable to the improper ventilation system of lift cars which would result into air pressure build-up in the lift car especially duringthe downward journey.

10.7 Match the static pressure $\mathrm{v} / \mathrm{s}$ airflow characteristic of the car with that of a fan.

From the principles of ventilation, for any system, for every value of airflow, there is a unique value of static pressure. For any system, the static pressure (resistance) changes as the square of the airflow, and the airflow is directly proportional to the RPM of the fan. Thus, for effective ventilation of a lift car, the static pressure $\mathrm{v} / \mathrm{s}$ airflow characteristic of the lift car has to be established and that shall be superimposed on the fan characteristic to get the operating point; thus check if the resultant airflow is at least equal to the desired flow. Also, sensitivity analysis should be carried out to check likely changes in the airflow concerning any changes in the system resistance. It might be beneficial if the fan(s) controller can run the fan at more than two speeds so that the requirement of matching the airflow with a different static pressure can be met. 
10.8 Enhance the air quality by purification methods

Other methods for purifying the air in the lift car have been reported. Photocatalytic Oxidation (PCO) technology (Kone 2020); Plasmacluster ion technology are some of them. These could enhance the quality of air in the lift cabin by supplementing the improved ventilation system.

\section{Conclusion}

In the pandemic situation of COVID-19, every effort to mitigate the spread of the virus must be done. The typical ventilation system of a lift car does not change the air in the car quickly enough. To remove the possibility of spreading the virus during lift travel with or without affected co-passengers, the concept of natural ventilation of lift cars should be changed. The ventilation system should be forced ventilation using pressure fans based on the required number of air changes per hour for exhausting contaminated air from the lift car. There could be a requirement to change the air 3 - 6 times per minute for the lift car depending on the environment in which the lift operates, the RTT (Round Trip Time for the lift to complete one trip starting from the ground floor and coming back to it after discharging passengers to their destination floors), etc.

A proper study of resistance to airflow in the lift car has to be carried out to determine static pressure requirements for the proper selection of pressure fans for effective air changes and also to decide on the areas of, and locations for, the air ventilation apertures.

Forced ventilation of the lift car is vital in the case of hospital lifts carrying patients, staff, visitors, etc. together or separately.

Some lift manufacturing companies have reportedly developed or used air purifiers which may help improve the quality of the air in the lift car further if used in the car ventilation system.

A properly designed ventilation system for the lift car will benefit in both pandemic situations as well as non-pandemic situations. It is likely to benefit passengers in terms of better ride comfort in high-speed lifts which deteriorates on account of the piston effect. Also, in the case of mid-rise/high-rise buildings, there could be some reduction in passenger discomfort due to the popping of eardrums.

The improved ventilation will generally help in enhancing passenger comfort in normal rides, especially in tropical countries. In case a lift with passengers is stuck in the shaft for whatever reason, the improved ventilation system will keep people in a much healthier atmosphere till rescue operation is carried out. 


\section{Declarations}

Funding

No funding was received.

\section{Conflict of interest}

The authors declare that they have no conflict of interest.

Availability of data and material

Data used from a research paper. Its reference is listed.

\section{Code availability}

No new code was written or used for the calculations.

\section{Author's contributions}

All technical contribution is by PMT. Overall research direction and guidance are provided by VGV.

\section{Ethics approval}

The research is based on data available over the internet. Thus, no ethics approvals are required.

\section{Consent to participate}

There was no participation of individuals in this study.

\section{Consent to publish}

No human participation was involved in this study. 


\section{References}

Martin Z. Bazant \& John W. M. Bush.: A guideline to limit indoor airborne transmission of COVID-19. PNAS. 118. 17. (2021). https://doi.org/10. 1073/pnas. 2018995118

Shen J et al.: Prevention and control of COVID-19 in public transportation Experience from China. Environmental pollution 266:115291. (2020)

Tang, J. et al.: Dismantling myths on the airborne transmission of severe acute respiratory syndrome coronavirus (SARS-CoV-2). Journal of Hospital Infection. (2021)

Miller, Shelly L., et al.: Transmission of SARS-CoV-2 by inhalation of respiratory aerosol in the Skagit Valley Chorale super spreading event. Indoor air 31.2. 314-323. (2021)

Tang, Julian W., et al.: Covid-19 has redefined airborne transmission. BMJ. 373. (2021)

Riediker, M. \& Tsai, D.: Estimation of Viral Aerosol Emissions From Simulated Individuals With Asymptomatic to Moderate Coronavirus Disease 2019. JAMA Netw Open. 3, e2013807-e2013807. (2020). doi:10.1001/ jamanetworkopen.2020.13807

International Standards Organization. ISO 8100-1 Lifts for the transport of persons and goods - Part 1: Passenger and goods passenger lifts (2019)

Bureau of Indian Standards. IS 14665 electric traction lifts Part 4 Componets: Section 3 - Lift Car frame, Car, Counterweight and Suspension (2001)

The American Society of Mechanical Engineers. ASME A17.1/CSA B44-16. Safety Code for Elevators and Escalators

European Committee for Standardization (EN 81) Safety rules for the construction and installation of lifts - Lifts for the transport of persons and goods - Part 20: Passenger and goods passenger lifts

https://bio.libretexts.org/Bookshelves/Introductory_and_General_ Biology/Book\\%3A_General_Biology_(Boundless)/39\\%3A_The_ Respiratory_System/39.2\\%3A_Gas_Exchange_across_Respiratory_ Surfaces/39.2C\\%3A_Lung_Volumes_and_Capacities

Flenady, T., Dwyer, T., \& Applegarth, J.: Accurate respiratory rates count: So should you!. Australas Emerg Nurs J. 20, 45-47. (2017). https://doi. org/10.1016/j.aenj.2016.12.003

Brigham, R., Machireddy, M., \& Sequeira, Y.: Don't Breathe on Me. (2019)

Bureau of Indian Standards. National Building Code of India - 2016

www.kone.com KONE introduces solutions for healthier and safer people flow environments: press release published 11/05/2020 